Vol. 20(2011): 96-114.

\title{
Recorded and potential alien invertebrate pests in Finnish agriculture and horticulture
}

\author{
Irene Vänninen ${ }^{1}$, Susan Worner $^{2}$, Erja Huusela-Veistola ${ }^{1}$, Tuomo Tuovinen ${ }^{1}$, Anne Nissinen ${ }^{1}$ \\ and Kari Saikkonen ${ }^{1}$ \\ ${ }^{1}$ MTT Agrifood Research Finland, Plant Production Research, FI-31600 Jokioinen, Finland \\ ${ }^{2}$ Bio-Protection Research Centre, Lincoln University, Lincoln, Canterbury, New Zealand \\ e-mail:irene.vanninen@mtt.fi
}

\begin{abstract}
It is assumed that climate change will promote pest invasions and their establishment in new regions. We have updated the list of current alien invertebrate pest species in Finland and produced a list of potential new alien pests using a self-organizing map (SOM) that ranks species in terms of their risk of entry into Finland. The 77 pest species recorded included 67 insects, 5 nematodes, 2 mites and 3 slugs. Nearly half of the alien species appeared to have invaded Finland during the last 48 years. The SOM analysis is considered a viable tool for identification of potentially high-risk invasive pests from among the multitude of potential alien invaders, and represents a useful complement to local expert knowledge-based risk assessment of potentially invasive pests. Along with the comparisons with databases of current and potential pest species, SOM analysis suggests that in the changing climate, the habitats at greatest risk from exotic pests in Finland are horticultural: orchards, ornamental hardy-nursery stocks, landscape and ornamental tree nurseries, and greenhouses.
\end{abstract}

Key-words: climate change, species invasions, Insecta, Mollusca, Nematoda, Acari, self-organizing map, pest control 
Vol. 20(2011): 96-114.

\section{Introduction}

It is expected that climate warming will be particularly pronounced at high latitudes, which will expand suitable cropping areas further northwards in Europe (IPCC 2007a, b). Increased atmospheric $\mathrm{CO}_{2}$, prolonged thermal growing seasons and milder winters will enhance agriculture and horticulture, resulting in increasing yields and creating opportunities for introduction of new crop species and varieties in Nordic countries (Olesen and Bindi 2002, Peltonen-Sainio et al. 2009, Kaukoranta et al. 2010). However, there will be disadvantages associated with the increased need for plant protection against current and novel pests. A longer and warmer growing season may increase pest infestations by promoting population growth rate of both pest types, for example, through an increased number of reproductive cycles during the growing season, and milder winters could allow new pest species to overwinter (Cammel and Knight 1992, Olesen and Bindi 2002). On the other hand, seasonal changes in day length, from long days in summer to darkness in winter around the Arctic Circle, in conjunction with milder winter conditions, will increase the risk of frost damage and anoxia caused by waterlogging. These factors, along with accumulation of ice due to fluctuating freeze-thaw cycles, may constrain establishment of both new crop plants and invasive pests. The consequences of climate change to agriculture and horticulture are further complicated because of the multifarious and dynamic biotic interactions. For example, novel weed species may restrict indigenous plant species (e.g. Thiele and Otte 2007) or provide migration routes for pests and pathogens, and/or enable their establishment (e.g. Norris and Kogan 2000), and invading pests may act as vectors of plant pathogens (e.g. Lemmetty et al. 2011). Because climate warming may affect crop, weed, pest and pathogen species individually or in combination as a biotic community, the benefits to agriculture and horticulture accrue only if adaptive management strategies are based on comprehensive agroecological understanding, starting with knowledge about the extent and likelihood of establishment of novel pests.
Accumulating evidence suggests that the distributions of a variety of alien pest species are expanding or shifting towards the poles, and that the number of alien invertebrate species in Europe is on the increase, but is mainly confined to manmade habitats (Hickling et al. 2006, Roques et al. 2009). Approximately $15 \%$ of these species have colonized agricultural land (Roques et al. 2009). A study by Vappula (1962) is currently the most comprehensive compilation of both indigenous and alien pests of cultivated plants in Finnish agricultural habitats. By 1961, the last year covered by Vappula's compilation, a total of 1005 invertebrate and 55 vertebrate species had been recorded as causing damage to cultivated plants. However, crop systems, production methods, crop species and world trade have undergone considerable changes during the last 50 years (Stoate et al. 2001; 2009; Olesen and Bindi 2002). These changes have probably been accompanied by changes in the pest status of some indigenous invertebrate species (e.g. Huber et al. 2002) as well as introduction and establishment of several alien pest species to the country. Clearly, it is time that the lists of alien pest species in Finnish agriculture and horticulture are updated and the potential consequences of climate change for pest invasion of Finland are estimated.

Climate change may affect any stage of the alien species invasion process, from the introduction of a species into a novel environment, to its naturalization (Hellmann et al. 2008; Walther et al. 2009). However, a key issue is how to predict which species and populations are potentially invasive and for which there is a high likelihood of entry as well as subsequent establishment. One recent approach proposed to address this is to map the most likely indigenous donor regions of alien species to produce lists of species with a high likelihood of establishment (Gevrey et al. 2006). This can be done using a self-organizing map (SOM). The SOM analysis classifies geographic areas according to the similarity of their pest species assemblages on the basis of presence/absence data of species occurring in those areas. In so doing, the method goes beyond bioclimatic modelling that only considers climatic variables as determinants of a species' establishment in a given area. Climate, however, is 
Vänninen, I. et al. Alien invertebrate pests in Finland

not the only determinant of establishment in a new area. Other explanatory factors include similarities with the original habitat, other than regarding climate, similar pathways of arrival, host plants and the characteristics of invaded areas such as high disturbance and absence of specific diseases and natural enemies. By using species assemblages the SOM method implicitly takes such factors into account when calculating the risk of establishment of given species into a particular geographic area (Worner and Gevrey 2006; Gevrey et al. 2006; Peacock and Worner 2006, 2008).

The SOM method essentially narrows the search space that consists of all potential alien pest species that could invade a given geographical area. Paini et al. (2010) showed that the species risk list was unaffected by alterations of up to $20 \%$ of data over all regions. Furthermore, they concluded that SOMs can deliver a level of objectivity, which can complement current consultative processes employed by many biosecurity agencies around the world, providing a better overall assessment of invasion risk. Risk indices created by SOM could serve as a guiding tool for plant health authorities when they make decisions concerning the allocation of resources to monitoring alien pests in imported produce. The risk indices can also be used as guidelines for decision-making on new pests that should be included in plant health legislation or, in the case that they are not regulated pests, should be considered at developing monitoring and management methods in a timely fashion. This is particularly important with respect to climate change, which can increase the risk of establishment of alien species, either because climatic conditions become more favourable for the species in question, or because a pest's host plants are taken increasingly into cultivation.

The first objective of this paper is to produce an updated list of confirmed invasive alien invertebrate pest species in Finnish agriculture and horticulture. The second objective is to estimate the establishment risk potential of insect pests that are not currently present in Finland but that pose a potential risk of invasion either under current or future climatic conditions.

\section{Methods}

\section{Definition of pest and their impact}

A pest is any species, strain or biotype of plant, animal or pathogenic agent injurious to plants or plant products (IPPC 1997; FAO 2002, 2004), even if the injurious effect is indirect through, for example, competition and harming those species that are beneficial to plants. To be classified as a pest an organism must have an economic impact or cause economic losses that are unacceptable. As our focus is the pest potential of alien species in Finnish conditions, our definition of invasive pest necessarily includes socio-economic values of causing harm to as well as harming agroecosystem functions after the pest has successfully established and is reproducing and spreading locally. Here, we consider as pests only those species that feed on horticultural or agricultural plants of economic importance and exlude species that feed on indigenous non-economic plant species. See Glossary in the Supplemental material for definitions of pest categories (alien, indigenous, introduced, invasive, quarantine, regulated, non-regulated).

The pest lists in this paper include three types of alien invertebrates as defined in the phytosanitary terms of the International Plant Protection Convention (IPPC) (FAO 2002, 2004): quarantine species, regulated non-quarantine species, and nonregulated non-quarantine species (Table 1). By definition, we consider a pest to be alien if it is introduced to Finland from its indigenous range by intentional or unintentional human action. Although economic impact of quarantine and non-regulated non-quarantine pests is often unpredictable, their potential impact is predictable because of their known economic importance elsewhere (Table 1). The relevant factors determining economically unacceptable impacts include: reduction in quantity or quality of marketable yield; extra costs of pest control (e.g. roguing, pesticide application); extra costs of harvesting and grading; costs of replanting (e.g. due to loss of longevity of plants); and loss due to the necessity of growing substitute crops (e.g. due to need to plant lower yielding resistant 
Vol. 20(2011): 96-114.

Table 1. Comparison of different alien pest categories for pest status, economic impact and application of official control. Modified from FAO (2002).

\begin{tabular}{llll}
\hline Defining status & 1. Quarantine pest & $\begin{array}{l}\text { 2. Regulated non-quaran- } \\
\text { tine pest }\end{array}$ & 3. Non-regulated non-quarantine pest \\
\hline Pest status & $\begin{array}{l}\text { Absent or limited } \\
\text { distribution }\end{array}$ & $\begin{array}{l}\text { Present and may be widely } \\
\text { distributed }\end{array}$ & $\begin{array}{l}\text { A) Absent, but with a high likelihood of entry. } \\
\text { B) Present, whereupon extent of distribution } \\
\text { varies depending on the stage of the invasion } \\
\text { process }\end{array}$ \\
Economic impact & Impact is predicted & Impact is known & 1) Impact is predicted \\
Official control & $\begin{array}{l}\text { Under official control Under official control with- } \\
\text { if present with the } \\
\text { aim of eradication or } \\
\text { containment }\end{array}$ & $\begin{array}{l}\text { respect to the specified plants } \\
\text { for planting with the aim of } \\
\text { suppression. }\end{array}$ & $\begin{array}{l}\text { Dhen present, management may be need- } \\
\text { ed if population densities approach damage } \\
\text { threshold. }\end{array}$ \\
\hline
\end{tabular}

varieties of the same crop or different crops) (FAO 2002). Further details defining economic impact can be found in FAO (2008).

\section{Information sources for species of confirmed introduction or presence in Finland}

The expert-knowledge-based list of confirmed invertebrate pests of Finnish agriculture and horticulture was compiled using three major types of information sources. As the first step, a list of alien invertebrate pest species that are already present in Finland was compiled on the basis of published and updated checklists and atlases of insects of Finland (Vappula 1962, Albrecht et al. 2008, Kettunen 2008, Kahanpää 2009, Kullberg et al. 2008, Albrecht 2010, The Finnish Expert Group on Coleoptera 2010). The second step was to consult the knowledge databases accumulated over the years by the researchers of plant protection at MTT in collaboration with their research and extension partners including also unpublished species identifications by the MTT staff. Here we included also those alien arthropod pest species that recently arrived unaided by humans and that have since either established or are colonizing Finnish sites, and which subsequently have been shown to be able to cause damage to agricultural or horticultural crops in their new distribution area. Third, the interception and survey databases of the Finnish Food Safety Authority (Evira) were consulted to list species that were intercepted by the official plant health inspection system between 2005-2009. These species belong to three categories: those intercepted in plant material arriving either from outside or from within the EU, and those that reached production sites and were detected there. Lastly, the DAISIE (2008a) website for Finnish records was consulted to check for the correspondence between our list and the DAISIE (2008a) records. Since some of the invertebrate checklists and atlases that we used explicitly specify which species are introduced or alien, whereas others do not, we cross-checked the alien status of the species in Europe in the DAISIE Handbook (DAISIE 2008b).

\section{Ranking species according to their of- ficial pest status and invasion stage}

We adopted the concept of five stages of invasion process as defined in Hellman et al. (2008) to estimate the invasion stage of the alien pest species: (1) transport stage: propagules arrive in the potential 
Vänninen, I. et al. Alien invertebrate pests in Finland

new distribution area but they may die there either due to abiotic conditions or eradication measures, (2) colonization stage: propagules in the new area of distribution survive but population may not grow due to biotic interactions, (3) establishment stage: the population in the new area of distribution grows but it may not form any new populations, (4) landscape spread stage: the alien species has bypassed biotic and abiotic barriers and is forming new populations in its new distribution area, and (5) naturalized: the species survives in its new area in the absence of cultivated plants.

\section{Estimating the change in the number of alien invertebrate pests since 1962}

The compilation made by Vappula (1962) was used to estimate the number of alien species that are present in Finland currently compared with 48 years ago. This was done by counting how many of the species in our list were included in Vappula (1962) and how many were new compared to the account of Vappula. This gave a crude estimation for the number of alien pest species having arrived in Finland since 1962.

\section{Information sources for pest species considered as potential risks by the European Union and in national plant health legislation}

To address the potentially pestiferous invertebrates, we used the European Council directive 2000/29/EC (EC 2000) and the statutes and decrees in Finnish plant health legislation as a source for species that are considered to threaten Finnish plant production (Ministry of Agriculture and Forestry (MMM) 1994, 1996, 2000, 2006, 2008, 2010).

Next, EPPO (European and Mediterranean Plant Protection Organization) A1, A2, and Alert lists (EPPO 2009ab, 2010) were consulted to include potentially threatening species that are not yet covered by the Finnish plant health legislation. We focused on species that EPPO considers important threats either for the whole EPPO region (e.g. greenhouse pests) or its northern parts (mainly forest and fruit tree pests). Last, we consulted the Pest Reports database of IPPC for alien pests that were intercepted in imported plant material or detected in production sites in the north-western European countries. Of these, we included those that were not covered by the procedure described previously. Additionally, species of Coccoidea found most frequently in greenhouses in France (Germain et al. 2003; Matile-Ferrero et al. 2004; Germain and Matile-Ferrero 2005) were included for consideration of their potential to enter the country and establish there. Coccoidea usually are among the most frequently introduced species in inventories of introduced species, particularly on imported woody ornamentals (e.g. Kenis et al. 2007).

\section{Estimating the risk of establishment of alien insect pests in Finnish agriculture and horticulture}

Worner and Gevrey (2006) developed a tool for predicting the establishment risk of alien insect pests in a given geographic area. The tool's usefulness was subsequently further scrutinized and evaluated by Gevrey et al. (2006), Gevrey and Worner (2006), and Watts and Worner (2008ab). The method uses global presence/absence data of insect crop pests based on the CABI (Commonwealth Agricultural Bureau International) Crop Protection Compendium (CABI 2003) and utilizes a SOM to categorize regions based on similarities in species assemblages. The method is based on the hypothesis that global insect pest assemblages are non-random species groupings that can be subjected to traditional community analysis (Worner and Gevrey 2006). The SOM method can, in principle, be used for any taxonomic group of species, not only insects; the only condition is that there are sufficiently reliable presence/absence data available on a global basis.

To produce predictive risk indices for alien pest species in Finland, a SOM analysis using the 
Vol. 20(2011): 96-114.

CABI (2003) global pest database was conducted as described in Worner and Gevrey (2006). A total of 844 insect species were included in the analysis. However, after the first analysis the presence/ absence data for Finland were checked from the created risk list and corrected for observed errors in the CABI database. Subsequently a final analysis was performed with the new, corrected data. The results of the two analyses did not differ from each other significantly (in accordance with the tolerance limits described in Paini et al. 2010). Therefore, only the results based on the corrected data were used when scrutinizing the risk indices. For the purposes of scrutinizing the risk list, we used the following five categories of establishment risk: high risk (index 0.7-1.0), medium-high (0.5-0.69), medium-low (0.3-0.49), low (0.1-0.29), and very low $(<0.1)$. By combining the medium-high and medium-low and omitting the very low risk categories, we arrived at the same three establishment risk categories used by Paini et al. (2010).

Because the SOM analysis uses pest species assemblages, species risk indices for a given geographic area are produced for both native species and alien species. This allows the comparison of characteristics for species placed in different risk index categories (high, medium, low, very low) and among indigenous, confirmed alien and absent alien species within a given risk index category. To represent reality meaningfully, the SOM should rank most of the indigenous species and most of the confirmed alien species in the high risk category, whereas the number and proportion of absent alien species should increase towards the low and very low risk index categories. Therefore, we approached the results of the SOM analysis with the following questions:

1) What are the characteristics of an alien species already present in Finland in comparison with the indigenous species that have a similar risk index? The characteristics we were mostly interested in were taxonomic status, the type of habitats the species usually occur in as pests, and establishment potential in outdoor habitats.

2) Which species/what type of species among the non-established alien ones have the highest risk indices, i.e. to what extent do these species corre- spond to the characteristics of those alien species that have already entered Finland and form permanent populations here? The answer to this question would pinpoint the species that are the most likely to establish in Finland also later on.

3) If there are any established alien species in the low and very low risk categories, what characteristics have allowed them to enter and establish in Finland? Such establishment incidences would serve as a guide to prepare for unpredicted introductions at a general level.

\section{Results and discussion}

\section{An updated list of confirmed alien inver- tebrate pest species in Finnish agricul- ture and horticulture}

Insects, mostly hemipterans, dominate the current alien invertebrate pest assemblage in Finnish agriculture and horticulture (Appendix 1 in Supplementary material available in journal's website). This is in concordance with similar inventories from elsewhere (e.g. Kenis et al. 2007). Of the 77 pest species reportedly having either entered Finland and established here, or have been intercepted in plant material at least once (without reaching places of production), 67 are insects and 5 are nematodes. Molluscs are represented by three species and mites by two. Alien insects pests include Hemiptera (39 species), Thysanoptera (10), Coleoptera (8), Lepidoptera (4), Diptera (3) and Hymenoptera (1 species). Of the hemipterans, the majority are aphids (20 species) and soft or hard scales (11 species), whereas heteropteran bugs, whiteflies, psyllids, and cicadellids are each represented by 2-3 species. Forty three species of those listed in Appendix 1 have reached the colonization stage or advanced beyond that, while the rest 34 species are either being transported to our country, or their current invasion status is not exactly known. Of those 43 species that are known to have reached at least the colonization stage, $52 \%$ are greenhouse pests, $25 \%$ are pests of field crops, 
Vänninen, I. et al. Alien invertebrate pests in Finland

$21 \%$ are pests of woody ornamental or fruit trees, and $2 \%$ are pests of herbaceous outdoor perennials. Greenhouse pests form the absolute majority of pests whose invasion stage is not exactly known, have been detected at least once in Finland or are in the transportation stage. From these figures and proportions it can be concluded that horticultural habitats and crops face a higher pressure by alien inverterbrate pests than field crops.

More than half of the confirmed alien invertebrate pest species (43 of 77) were listed in DAISIE (2008b) as alien to Europe, and 17 species are indigenous to Europe, but have subsequently been distributed intentionally or unintentionally outside their indigenous area of distribution, in this case to Finland. Six of the species in Appendix 1 are of obscure origin according to DAISIE (2008b). Altogether there are 50 species in Appendix 1 (see the column eight) that are not reported as having been detected in Finland in the DAISIE (2008a) website records. Eleven species in Appendix 1 (symbol "__“ in column nine) are indigenous to Europe but alien to Finland, however they are not listed as having spread outside their original range in Europe in DAISIE (2008b). These species are Cacopsylla melanoneura and Psylla buxi that represent pests of fruit and Buxus trees, respectively, the cicadellid Igutettix oculatus, Anthonomus pomorum, Lepidosaphes conchyformis, Rhopalosiphoninus staphyleae, Macrosiphum hellebori, Coloradoa rufomaculata, Aulacorthum circumflexum, A. solani, and Nesidiocoris tenuis.

Thirty five species of the 77 listed in Appendix 1 are known to have entered Finland before 1962, and are mentioned in Vappula (1962), whereas 42 are not mentioned. This suggests that over half of the currently listed alien species (Appendix 1) have entered Finland during the last 48 years.

Eleven species of alien aphids that have been recorded in Finland (Aulacorthum circumflexum, A. solani, Cerataphis orchedearum, Coloradoa rufomaculata, Aphis gossypii, Dysaphis tulipae, Myzus ornatus, Myzus ascalonicus, Rhodobium porosum, Illinoia azaleae, Macrosiphoniella sanborni) are either known or suspected to be able to overwinter only indoors in our conditions (Heie 1994). The species Macrosiphum hellebori and
Rhophalosiphoninus staphyleae are, according to Albrecht (2010), found only indoors in Finland, but no exact information on their overwintering capacity is available. The frequency of occurrence of alien aphid species indoors has not been studied.

Sixty six percent of the reported alien species are pests of greenhouse crops or survive in other indoor habitats such as plant retail shops. These species mostly include aphids, hard and soft scales, thrips, whiteflies and leafminer flies (Agromyzidae). Eleven species, or $16 \%$ of the total, representing predominantly Lepidoptera and Coccoidea, are pests of woody plants: fruit trees or woody ornamental trees and shrubs (deciduous and coniferous species). Twelve species (16\%) are pests of various field or garden crops (potato, Brassica-crops, cereals, grasses). The invasion status or frequency of occurrence of many of the alien hemipteran species, particularly aphids and scale insects, is not known precisely. Many of the species are assumed to be repeatedly introduced on imported plant material, but no surveys have been made during recent years to confirm their frequency of occurrence in actual places of production.

Five alien insect pest species of quarantine status have been intercepted on imported plant material but are not known to have reached places of production to date: Thrips palmi, Helicoverpa armigera, Anoplophora glabripennis, Bursaphelenchus xylophilus and Globodera pallida. Another four quarantine insect species crossed the border and reached places of production, but were eradicated: Bemisia tabaci, Liriomyza huidobrensis, L. trifolii and Spodoptera littoralis. The fifth species, Leptinotarsa decemlineata (the Colorado potato beetle) has entered Finland with prevailing winds from the St. Petersburg region and the Baltic countries, but the occurrences have been eradicated.

\section{Predicting invasion risk of novel pests into Finland}

The proportion of both indigenous and alien species confirmed as present in Finland decreased with decreasing risk category. The SOM method 
Vol. 20(2011): 96-114.

was thus able to predict the establishment risk of pests in accordance with the observed reality. The proportion of indigenous species in the high and medium-high risk categories was $72 \%$ and $65 \%$, respectively, but dropped to $38 \%$ in the medium-low risk class and to $5 \%$ in the low risk category (Fig. 1). No indigenous species were placed in the very low risk category. The risk indices of indigenous species tend to reflect their distributional range and abundance in Finland, but also, and in particular, their prevalence in the larger database. For example, the distribution of the indigenous species placed in the low risk category using SOM analysis is either restricted to southern Finland, or the species are relatively rare in the country and do not form abundant populations. This group of 12 species includes one migrant Lepidoptera species, and one stored grain insect. The medium-low risk category of indigenous insects also includes species with relatively restricted distributions and low abundances, or pest species of only minor importance. Thus there seems to be a tendency for the indigenous species to become more widespread and more abundant on moving from the low risk category towards the higher risk categories. This tentative conclusion requires closer inspection and is a task to be addressed during further studies on predicting the potential of indigenous insect species to increase in importance as pests as climate change progresses.
In the SOM analysis utilizing the CABI (2003) database, the alien species that are known to be present in Finland comprised 19\% of all species that were placed in the high risk category, $8 \%$ in the medium-high category, and 10\% in the mediumlow categories, respectively (average of $9 \%$ in the combined medium-categories), but only $4 \%$ in the low risk category (Fig. 1). Thus with each downward step between the three risk categories (high, medium, and low), the proportion of confirmed alien species was halved, with no change between the medium-high and medium-low categories. This was accompanied by at least a doubling of the proportion of alien species that are still absent from Finland with every decreasing step in the successive risk categories: from $8.4 \%$ in the high risk category to $26.7 \%, 51.6 \%$ and $90.9 \%$ in the medium-high, medium-low and low risk categories, respectively.

\section{Characteristics of alien insect species confirmed as present in Finland}

The findings that the proportion of indigenous species remained unchanged between the high and medium-high risk categories and that the proportion

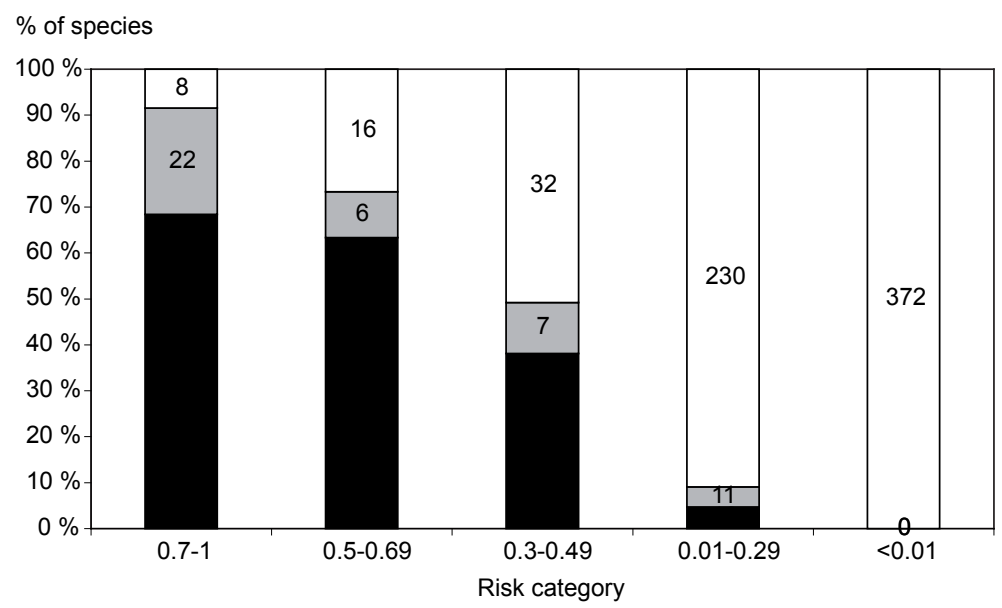

$\square$ Alien, absent $\square$ Alien, present $\square$ Native
Fig.1. Number and relative proportion of indigenous, confirmed alien and absent alien pest insect species in different establishment risk categories according to the results of the SOM analysis. 
Vänninen, I. et al. Alien invertebrate pests in Finland

of confirmed alien species did not change between the medium-high and medium-low risk categories prompted us to look more closely at the qualitative characteristics of the species in these categories. By scrutinizing the biological and ecological characteristics of both indigenous and confirmed alien species in the different risk categories we used these species characteristics as references when expanding on the predicted risk of the potentially novel pest species placed in the same risk categories by the SOM analysis.

The risk indices, produced by the SOM analysis and shown in Appendix 1 for different species, show that among the alien insect species already recorded in Finland, all outdoor pests had a risk index of 0.5 or higher. This 0.5 threshold for the risk of an alien insect species establishing in outdoor habitats reflects the time when the global database was last updated (CABI 2003) and is therefore considered to hold for insects in the current climatic conditions. Table 2 further highlights the point of established outdoor pests obtaining a risk index of 0.5 or higher. Table 2 lists those alien species that have been recorded in Finland and that were included in the CABI database used for the SOM analysis. Note that the species lists of Appendix 1 and Table 2 are not totally similar, because all species known to have entered Finland (Appendix 1) are not included among the 844 species used for the SOM analysis. Table 2 therefore has fewer species than Appendix 1. Furthermore, Table 2 includes species that are not listed in Appendix 1. These include the Lepidoptera Peridroma saucia, Autographa gamma, Malacosoma neustria, Agrius convolvuli and Autographa gamma, all of which are rare migrants except $A$. gamma that forms abundant populations in some years. None of these Lepidoptera species is known to overwinter in Finland. Table 2 includes also several species of stored products that we deliberately excluded from Appendix 1 which gives pests of crop plants. In the SOM analysis shown in Table 2, the pests of stored products serve to highlight the fact that in addition to greenhouse species that also live in indoor conditions, the stored product pests were the only alien species in the low risk category to have established in Finland. This suggests that the SOM method, at least when utilizing the CABI database, does not produce reliable establishment risk indices for species that live in indoor habitats in our conditions, but tends to underestimate their establishment potential.

The majority of alien insect species already recorded from Finland and therefore with a high risk index in the SOM analysis are known as pests of outdoor crops which include both field crops, fruit trees and woody ornamentals (Fig. 2). On the other hand, only two species in the medium-high establishment risk category are pests of outdoor crops, whereas all species in the medium-low and low risk categories are pests of stored products or greenhouse crops (Fig. 2). Such qualitative differences in the habitat requirements of species between the medium-high and medium-low and low risk categories further corroborates our conclusion that the risk level of 0.5 appears to be the dividing line for the capacity of alien insect species to establish in outdoor habitats and form permanent, self-perpetuating populations on a year-round basis in the current climatic conditions of Finland. On the other, this corroborates the already stated finding that the establishment risk indices for pests of indoor habitats can be low according to the SOM analysis, but despite this they establish more often in the target area than those of field crops with low risk indices.

\section{Novel alien species with potential to establish in Finland}

For alien species that currently have not been recorded in Finland the SOM model predicted high establishment risk indices for eight herbivores of outdoor crops (Table 3). Four of these species are pests of orchards and/or woody ornamentals and ornamental park trees. The other four are pests of miscellaneous field crops. The establishment potential of these species in outdoor habitats corresponds to that of already established alien species with a risk index of 0.5 or more. There is one quarantine (protected zone) pest in this group, Leptinotarsa decemlineata, and one (Eriosoma lanigerum) that is regulated by the statute concerning plant health 
Vol. 20(2011): 96-114.

Table 2. Risk indices, obtained with the SOM analysis, of alien insect pest species reportedly present in Finnish agriculture or horticulture (the forest pests are included to represent pests of hardy ornamental nursery stock and park trees). The list includes also few species that are not strictly in-troduced species, but which regularly migrate to Finland from other areas but are known not to form overwintering populations. Habitat codes: $\mathrm{O}=$ orchards and woody ornamentals, $\mathrm{G}=$ greenhouses, $\mathrm{F}=$ field (row) crops, $\mathrm{S}=$ stored products. Note that not all species listed in Appendix 1 are included in this table, because the CABI (2003) database does not include all species listed in Appendix 1.

\begin{tabular}{|c|c|c|c|c|}
\hline Risk category & Species & Family (order) & Risk index & Habitat \\
\hline \multirow[t]{21}{*}{$0.7-1$} & Plutella xylostella & Plutellidae (Lep.) & 0.9510 & $\mathrm{~F}$ \\
\hline & Myzus persicae & Aphididae (Hom.) & 0.9472 & G \\
\hline & Peridroma saucia & Noctuidae (Lep.) & 0.9450 & $\mathrm{~F}$ \\
\hline & Aphis gossypii & Aphididae (Hom.) & 0.9064 & G \\
\hline & Otiorhynchus sulcatus & Curculionidae (Col.) & 0.8711 & $\mathrm{~F}$ \\
\hline & Pieris rapae & Pieridae (Lep.) & 0.8704 & $\mathrm{~F}$ \\
\hline & Frankliniella occidentalis & Thripidae (Thys.) & 0.8635 & G \\
\hline & Heliothrips haemorrhoidalis & Thripidae (Thys.) & 0.8259 & G \\
\hline & Rhopalosiphum insertum & Aphididae (Hem.) & 0.8253 & $\mathrm{O}$ \\
\hline & Anthonomus pomorum & Curculionidae (Col.) & 0.8172 & $\mathrm{O}$ \\
\hline & Agrius convolvuli & Noctuidae (Lep.) & 0.8166 & $\mathrm{~F}$ \\
\hline & Cacopsylla pyricola & Psyllidae (Hom.) & 0.8154 & $\mathrm{O}$ \\
\hline & Rhopalosiphum maidis & Aphididae (Hem.) & 0.8143 & $\mathrm{~F}$ \\
\hline & Pieris brassicae & Noctuidae (Lep.) & 0.7753 & $\mathrm{~F}$ \\
\hline & Melolontha melolontha & Scarabeidae (Col.) & 0.7728 & $\mathrm{~F}$ \\
\hline & Malacosoma neustria & Noctuidae (Lep.) & 0.7648 & $\mathrm{O}$ \\
\hline & Pseudococcus longispinus & Pseudococcidae (Hem.) & 0.7507 & G \\
\hline & Aphis craccivora & Aphididae (Hom.) & 0.7476 & $\mathrm{~F}$ \\
\hline & Macrosiphum euphorbiae & Aphididae (Hom.) & 0.7459 & G \\
\hline & Autographa gamma & Noctuidae (Lep.) & 0.7309 & $\mathrm{~F}$ \\
\hline & Ephestia elutella & Pyralidae (Lep.) & 0.7107 & $\mathrm{~S}$ \\
\hline \multirow[t]{6}{*}{$0.5-0.69$} & Saissetia coffeae & Coccidae (Hem.) & 0.6869 & G \\
\hline & Coccus hesperidum & Coccidae (Hem.) & 0.6754 & $\mathrm{G}$ \\
\hline & Acanthoscelides obtectus & Bruchidae (Col.) & 0.6183 & $\mathrm{~S}$ \\
\hline & Ceutorhynchus assimilis & Curculionidae (Col.) & 0.5429 & $\mathrm{~F}$ \\
\hline & Planococcus citri & Pseudococcidae (Hem.) & 0.5258 & G \\
\hline & Megastigmus spermotrophus & Torymidae (Hym.) & 0.5113 & $\mathrm{O}$ \\
\hline \multirow[t]{6}{*}{$0.3-0.49$} & Saissetia oleae & Coccidae (Hem.) & 0.4605 & G \\
\hline & Trialeurodes vaporariorum & Aleyrodidae (Hem.) & 0.4553 & G \\
\hline & Tribolium castaneum & Tenebrionidae (Col.) & 0.3376 & $\mathrm{~S}$ \\
\hline & Oryzaephilus surinamensis & Silvanidae (Col.) & 0.3280 & $\mathrm{~S}$ \\
\hline & Tribolium confusum & Tenebrionidae (Col.) & 0.3249 & $\mathrm{~S}$ \\
\hline & Cryptolestes pusillus & Cucujidae (Col.) & 0.3082 & $\mathrm{~S}$ \\
\hline \multirow[t]{12}{*}{$0.01-0.29$} & Cryptolestes ferrugineus & Cucujidae (Col.) & 0.2831 & $\mathrm{~S}$ \\
\hline & Alphitobius diaperinus & Tenebrionidae (Col.) & 0.2373 & $\mathrm{~S}$ \\
\hline & Plodia interpunctella & Pyralidae (Lep.) & 0.2228 & $\mathrm{~S}$ \\
\hline & Tenebroides mauritanicus & Tenebrionidae (Col.) & 0.1565 & $\mathrm{~S}$ \\
\hline & Typhaea stercorea & Mycetophagidae (Col.) & 0.1352 & $\mathrm{~S}$ \\
\hline & Oryzaephilus mercator & Silvanidae (Col.) & 0.1281 & $\mathrm{~S}$ \\
\hline & Rhopalosiphum rufiabdominale & Aphididae (Hem.) & 0.1073 & $\mathrm{G}$ \\
\hline & Galleria mellonella & Pyralidae (Lep.) & 0.08578 & $\mathrm{~S}$ \\
\hline & Trogoderma variabile & Dermestidae (Col.) & 0.0853 & $\mathrm{~S}$ \\
\hline & Ahasverus advena & Silvanidae (Col.) & 0.0853 & $\mathrm{~S}$ \\
\hline & Lasioderma serricorne & Anobiidae (Col.) & 0.0620 & $\mathrm{~S}$ \\
\hline & Macrosiphoniella sanborni & Aphididae (Hom.) & 0.0427 & $\mathrm{G}$ \\
\hline
\end{tabular}




\section{AGRICULTURAL AND FOOD SCIENCE}

Vänninen, I. et al. Alien invertebrate pests in Finland

Fig. 2. Principal habitats of alien insect species recorded in Finnish agriculture and horticulture based on results of the SOM analysis that used the CABI database. The proportions are based on habitat information given in Table 2.

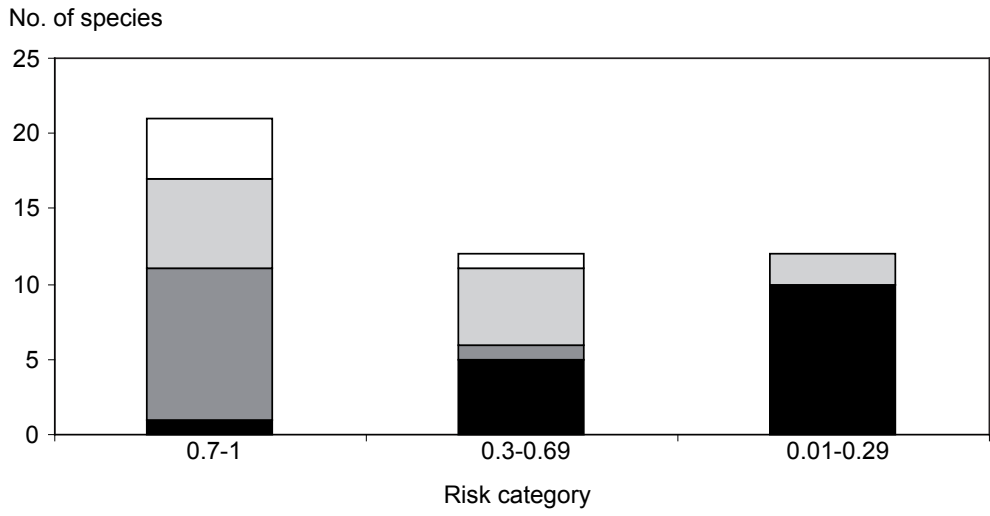

$\square$ Orchards and woody ornamentals

$\square$ Greenhouses

$\square$ Field crops (cereals, vegetables, beets, legumes etc.) - Stored products of fruit and berry plants and woody ornamentals. Ostrinia nubilalis has a high risk of establishment, but at the moment its main food plant, maize, is only grown to a very limited extent as a forage crop and in home gardens (sweetcorn). The species is, in fact, a migrant in Finland, and lives here on Artemisia and several Poaceae, producing two generations each summer. The observations made by lepidopterists suggest that it has become more common during the last 20 years (Jaakko Kullberg, pers. comm.). Locusta migratoria is a species that is thought to migrate to Finland in small numbers rather regularly, although some observations may represent specimens that escaped from rearing in captivity (Karjalainen 2008).

The majority of species with predicted medium establishment risk indices are pests of orchards, berry bushes, or woody ornamentals (Table 3 ). The alien species in the medium risk category may represent those with increasing establishment risk with climate change. Most of these potential invaders are hemipteran pests (hard and soft scales, aphids) and Lepidoptera, but weevils are also represented. There are nine species regulated by the Finnish plant health law and its statutes in this risk category of potential pests. Additionally, Diabrotica virgifera virgifera is included in the EPPO A2-list (EPPO 2009b). In further studies that focus on changes in pest potential with the progress of climate change, species in the high and medium risk groups should be subject to closer analysis in terms of their host-plant relationships and predictions concerning the development of the cultivation of their host plants in Finland in the future. Additionally, tri-trophic interactions, bioclimatic modelling, overwintering requirements and land use effects will need careful study.

The low risk category of the currently absent alien species (data not shown) includes a total of 220 species with variable habitat requirements and biology - at the same time, they may have a low prevalence globally in the database, which means they tend not to co-occur with other species in the pest assemblage, thus they get low weights in the SOM analysis (resulting in low establishment risk indices). Even here, hemipteran pests are again well represented among the potentially invasive pests. Of the 20 species at the upper end of this risk category (risk index 0.21-0.29), eight species belong to Coccoidea or Aleyrodidae.

Among potential insect pests in the high and medium risk categories, the proportion of species was divided relatively equally between agriculture (field crop pests 50\%) and horticulture (pests of orchards and woody ornamentals $35 \%$, pests of greenhouse crops $21 \%$ ). In the upper part of the low risk category (risk index 0.1-0.29), represented by 84 insect species, the proportion of field crop pests declined to $26 \%$, whereas that of horticultural pests increased to $70 \%$ (orchards and woody 
Vol. 20(2011): 96-114.

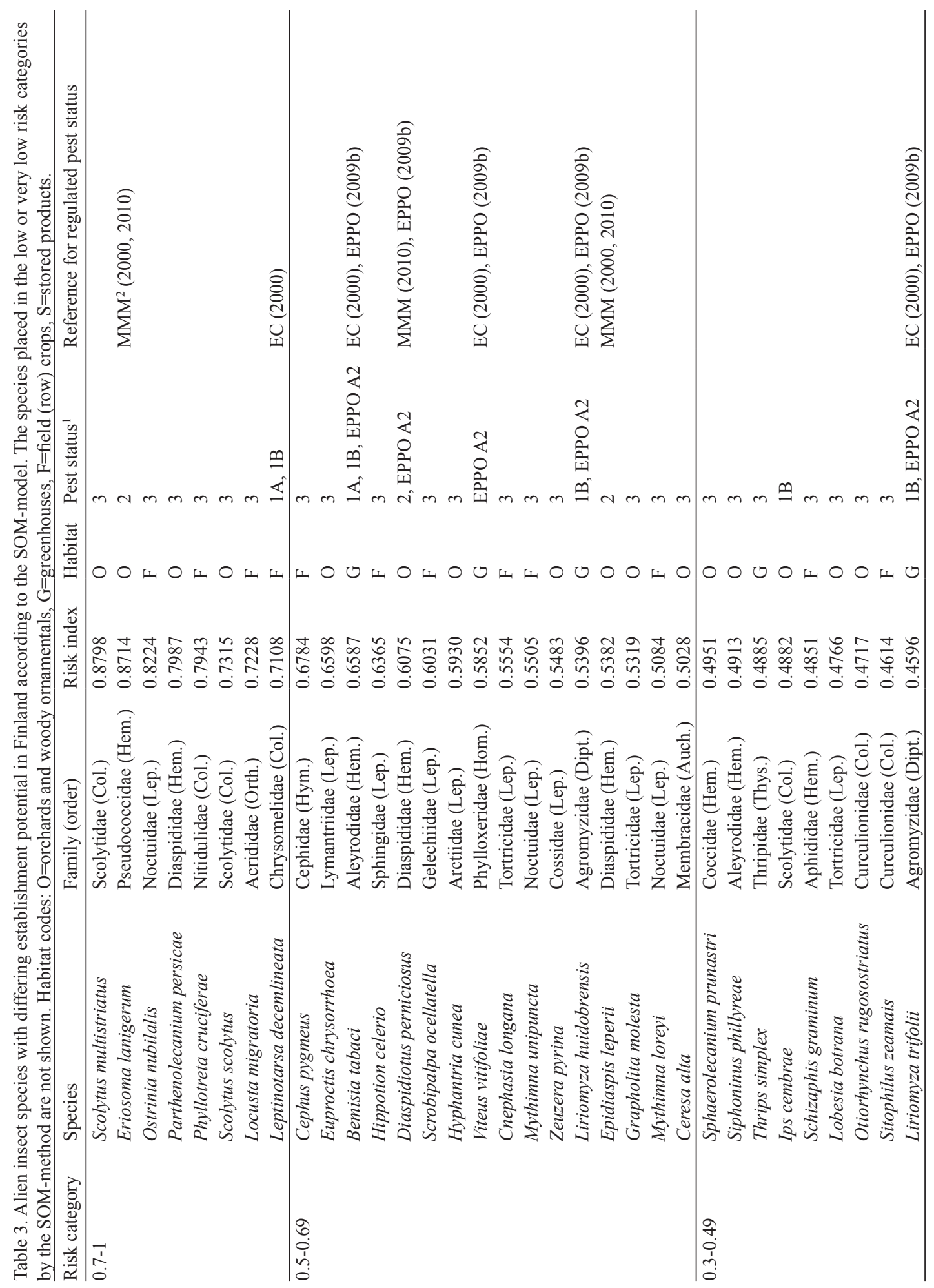


Vänninen, I. et al. Alien invertebrate pests in Finland

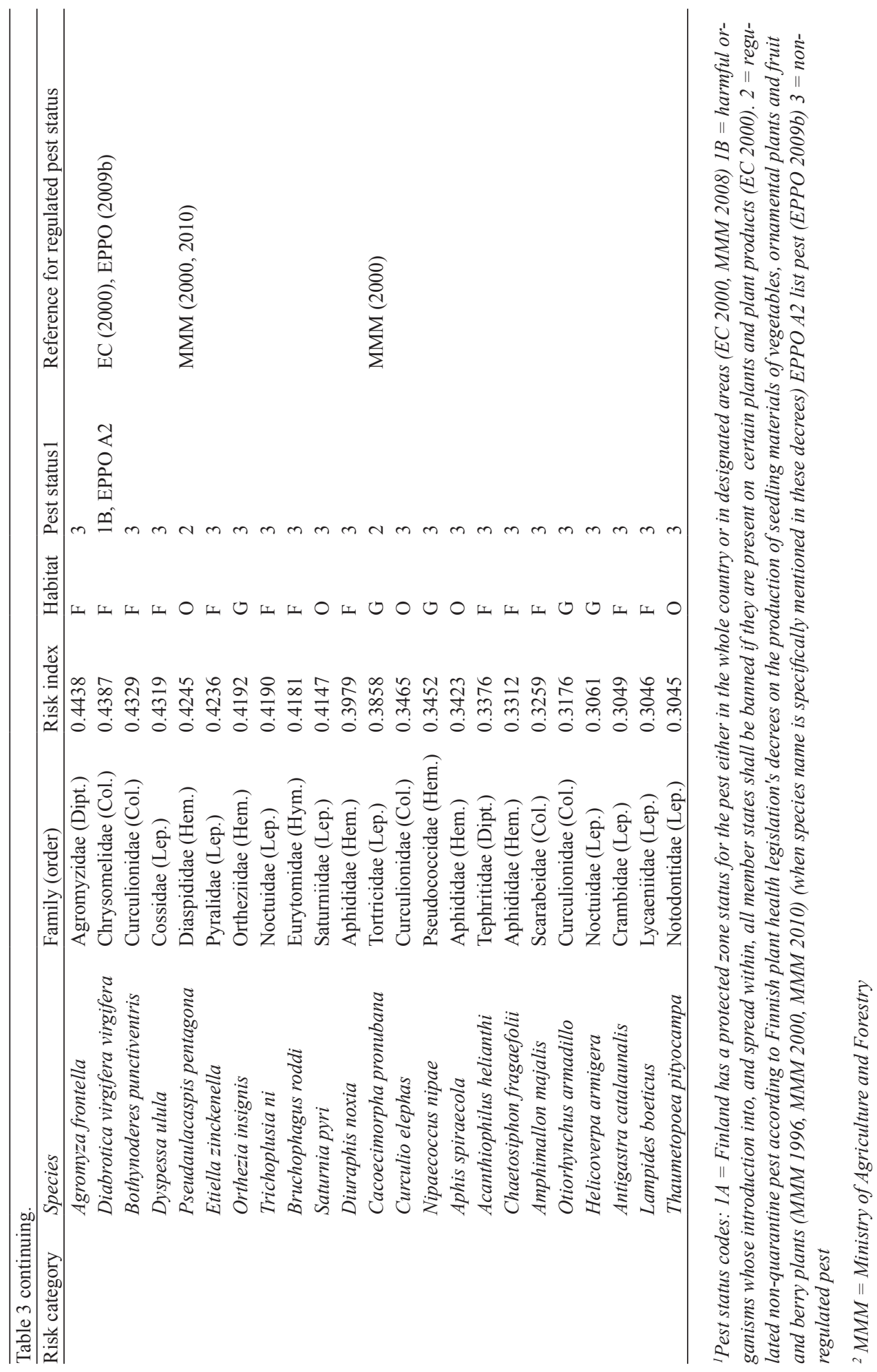


Vol. 20(2011): 96-114.

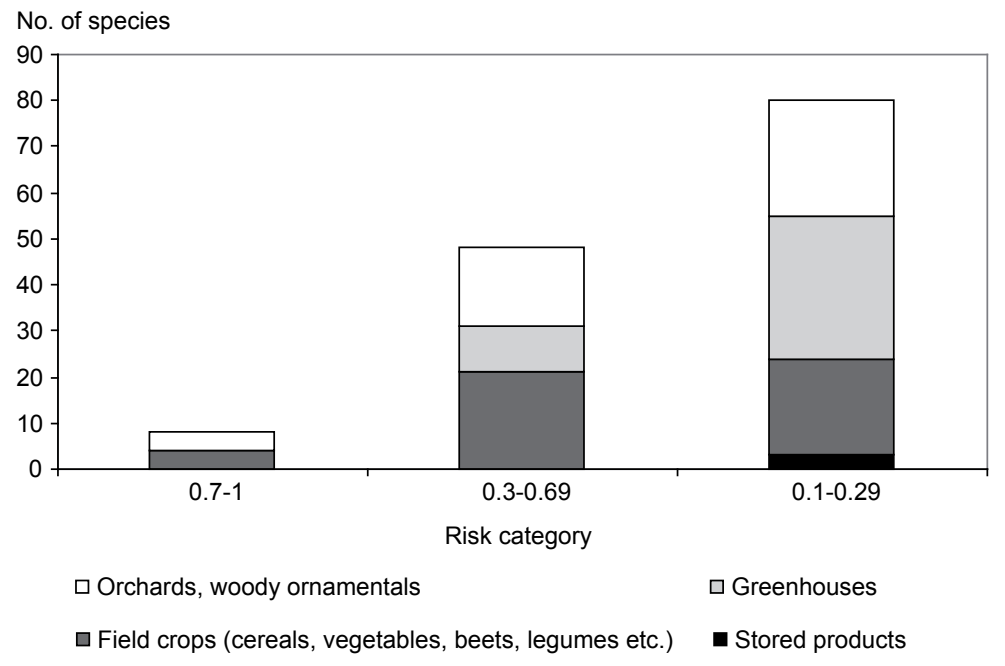

Fig. 3. Principal known habitats (in their current distribution ranges) of insect species that are potential pests of Finnish agriculture and horticulture according to the SOM analysis that utilized the CABI database. The proportions are based on habitat information shown in Table 3. For the low risk category, only 84 species of the total of 230 with a risk index of 0.1-0.29 were included in the figure. Species $(n=372)$ in the very low risk category are not shown in the figure. ornamentals 31\%, greenhouses 39\%) (Fig. 3). This suggests that measured strictly as the number of species, horticultural habitats appear to face more risks from alien pest species than field crop habitats. The fact that the majority of alien pests already recorded in Finland (Appendix 1) are pests of greenhouse crops corroborates this. More plant species, that can be associated with alien pest introductions, are imported to horticultural habitats, which may partly explain the above difference.

\section{Establishment risk of pests regulated by plant health legislation}

The analysis of risk indices of regulated species (Appendix 2 in Supplementary material) not covered in Table 3 and Appendix 1 draws attention to two issues. First, most of the 80 regulated species for which risk indices could be generated by the SOM analysis, and which are currently absent from Finland, were placed in the very low risk $(<0.1)$ category, and only 20 species received a low risk index (0.1-0.29). The latter represent species living in a variety of different habitats, but again most of them are pests of fruit trees, woody ornamentals or greenhouse crops (data not shown).
Factors such as pathway and its history, volume of traded goods, sources and destinations of imported plant material, and the intensity of eradication procedures may have stronger explanatory force than climatic factors for the establishment risk of greenhouse pests. An example of a species pair with different predicted risks of establishment in Finland is Bemisia tabaci and Trialeurodes vaporariorum (see Appendix 1). The former has an establishment risk index which is considerably higher than that of the latter, although the latter became established in Finnish greenhouses decades ago. However, the measures dictated by the Finnish plant health legislation keep $B$. tabaci from establishing in Finnish greenhouses under the current high propagule pressure. Another example is Thrips palmi, which got a very low risk index in the SOM analysis compared with an ecologically and biologically rather similar Frankliniella occidentalis (Appendix 1). Thrips palmi is intercepted annually in imported plant material. It is known from the UK that once the species gets into a greenhouse and a suitable host plant, it is very difficult to eradicate (MacLeod et al. 2004) even though it is not able to form permanent populations outdoors in the UK (McDonald et al. 1999, 2001). The situation is likely to be similar in Finland, al- 


\section{AGRICULTURAL AND FOOD SCIENCE}

Vänninen, I. et al. Alien invertebrate pests in Finland

though cooler and shorter summers may reduce the species' voltinism here under outdoor conditions. Furthermore, Thrips palmi is a species not established in the EU so far, and therefore its prevalence in the CABI database is low, leading to very low establishment risk prediction in the SOM analysis. The relative importance of different factors behind the establishment potential of greenhouse pests should be elaborated further in subsequent analysis. Other methods than those utilizing species assemblage information appear necessary for predicting establishment risk of indoor pests in a given geographical area. The general conclusion regarding the establishment risk of greenhouse and other indoor pests is that although the predicted risk indices may be low, in reality they are much more likely to establish if not prevented from doing that. This conclusion is corroborated by the fact that most alien pest insect species having reportedly been detected in Finland are pests of greenhouse crops (Appendix 1).

\section{Conclusions and recommendations}

High correlation of predicted risk of invasion by SOM analysis with indigenousness of the species suggests that the SOM analysis is a practical tool for identification of potentially high-risk invasive pests, and is therefore a useful complement to local expert knowledge-based risk assessment of potential invasive pests. Such predictive information should be useful when planning inspections of imported plant material. According to Moffitt et al. (2008), we are not only ignorant about potential invasive species introductions, we are also ignorant of the likelihood of these introductions. An increase in volume of traded plant material alone will not necessarily lead to an increase in the number of pests entering the target area of the traded materials, although in some cases this can be true (Areal et al. 2008). We must look at specifics, in other words, which species of plants are being considered, and which pests the plants are likely to carry (Areal et al. 2008). The risk indices obtained by the SOM-method should be seen as a starting point for narrowing down the species selection of alien pests that have the potential to establish in the new area in question, which can be combined with the ability of the SOM method to rank geographic areas according to the likelihood of the areas serving as sources of alien pest species. In this way monitoring resources could be better targeted without decreasing the likelihood of detecting the pests in imported plant material.

Along with databases of present and potential alien pest species, SOM analysis suggests that the greatest risks associated with exotic pests in Finnish agriculture and horticulture will fall rather evenly on crop production in agriculture (field crops) and horticulture (orchards, woody ornamentals, greenhouses) as comes to pests placed in the high and medium risk categories. There are, however, more pest species of horticultural crops than of field crops in the low risk category. Many of the low risk category pests live on greenhouse crops, for which the SOM prediction appears to perform poorly and may underestimate their establishment risk. Even species that receive a low risk index of establishment in the SOM analysis may be prone to establish in the greenhouse environments if they get access to them, particularly when greenhouse crops are grown year-round in cold climates. This emphasizes the importance of potential alien pests for Finnish horticultural crops. Further analyses are required on specific factors that to various degrees may influence the establishment risk of the alien species. These factors include bioclimatic conditions, host plant interactions, overwintering in respect to changing climatic conditions, the role of tri-trophic interactions in forming a barrier to the establishment of the introduced species, and proactive measures of pest management and extension services.

Alien hemipteran pests, particularly species in the Diaspididae, Coccidae, and Aphididae, were among those that appear to have the highest establishment risk in Finland. This is in accordance with their prevalence among introduced pests elsewhere. With climate change, the importance of hemipteran pests may grow further, as many 
Vol. 20(2011): 96-114.

of them can easily increase the number of generations per year with the predicted prolongation and warming-up of the growing season (Kiritani 2006; Bale et al. 2002). Furthermore, Hemiptera are estimated to either benefit from or show no negative response to increasing $\mathrm{CO}_{2}$ levels, in contrast with other feeding guilds of insects (Bezemer \& Jones 1998). In addition, many Heteroptera species have been shown to be in the process of expanding their distribution ranges through natural dispersal and migration (e.g. Aukema 2004).

The potential new alien species with risk indices higher than 0.7 suggests that they have a high likelihood of bypassing the abiotic and biotic barriers to colonisation and establishment under current climatic conditions. For outdoor alien pests under current climatic conditions, establishment appears possible when risk of establishment is 0.5 or higher. The progress of climate change may increase the ability of alien species with a risk index below 0.5 to establish in northern outdoor conditions, assuming that bioclimatic conditions are among the important factors that currently prevent their establishment in Finland. Bioclimatic modelling and consideration of other factors, such as host plant availability limiting establishment potential, are needed to verify it this assumption. The SOM method could be useful also for predicting cultivation possibilities of different crops in new areas in current conditions.

The list of confirmed alien pests in Finnish agriculture and horticulture can now be used to update the presence/absence data for Finland in international databases.

The list of confirmed alien pests in Finland suggests also that the DAISIE (2008a) database must be updated for information concerning the alien status of some species of European origin that have expanded their distribution outside their indigenous range to Finland, but are currently not listed as invasive species in the handbook.

Acknowledgements: We thank Guy Söderman at the Finnish Environment Institute, Kari Heliövaara and Jaakko Kullberg at the University of Helsinki, Veikko Rinne at the University of Turku, Kari Tiilikkala at MTT, and many others for their help in confirming the indigenousness status of several species in Appendix 1. We are grateful to Jukka Kettunen for confirming the identification of Liothrips vaneeckei and to Salla Hannunen and Ville Welling at the Finnish Food Safety Authority Evira for providing interception and eradication data for quarantine species.

\section{References}

Albrecht, A. 2010. Atlas of the Aphids of Finland. Cited 18 November 2010. Available on the Internet: http://www. luomus.fi/elaintiede/hyonteiset/tutkimus/kirvat/atlas.htm

Albrecht, A., Mattila, K., Rinne, V. \& Söderman, G. 2008. The Checklist of Finnish Hemiptera. Cited 14 June 2010. Available on the Internet: http://www.sci.utu.fi/projects/ biologia/elainmuseo/hemi/tyoryhma/Check-list_of_ Finnish_Hemiptera.pdf

Areal, F. J., Touz, J., MacLeod, A., Dehnen-Schmutz, K., Perrings, C., Palmieri, M. G. \& Spence, N. J. 2008. Integrating drivers influencing the detection of plant pests carried in the international cut flower trade. Journal of Environmental Management 89: 300-307.

Aukema, B. 2004. Recent changes in the Dutch Heteroptera. Het News, Newsletter of the Heteroptera Recording Schemes 3: 2-4. Cited 28 May 2010. Available on the Internet: http://www.hetnews.org.uk/pdfs/Issue\%203_ Spring\%202004_422Kb.pdf

Bale, J. S., Masters, G. J., Hodkinson, I. D. et al. 2002. Herbivory in global climate change research: direct effects of rising temperature on insect herbivores. Global Change Biology 8: 1-16.

Bezemer, T. M. \& Jones, H.T. 1998. Plant-insect herbivore interactions in elevated atmospheric $\mathrm{CO}_{2}$ : quantitative analyses and guild effects. Oikos 82: 212-222.

$\mathrm{CABI}$ (Commonwealth Agricultural Bureau International) 2008. Crop Protection Compendium (Alpha). Cited during March-April 2010. Available on the Internet: http:// www.cabi.org/cpc/default.aspx?site=161\&page $=868$.

$\mathrm{CABI}$ (Commonwealth Agricultural Bureau International) 2003. Crop Protection Compendium, Global Module, 5th ed. Wallingford, UK: CAB International.

Cammel, M. E. \& Knight, J. D. 1992. Effects of climatic change on the population dynamics of crop pests. Advances in Ecological Research 22: 117-162.

DAISIE 2008a. Delivering Alien Invasive Species Inventories for Europe. Database. http://www.europe-aliens. org/index.do

DAISIE 2008b. Handbook of alien species in Europe. Dordrecht: Springer. 399 p.

EC (European Council) 2000. Council directive 2000/29/ EC of 8 May 2000 on protective measures against the introduction into the Community of organisms harmful to plants or plant products and against their spread within the Community. Cited 5 Nov, 2010. Available on the Internet: http://eur-lex.europa.eu/LexUriServ/LexUriServ. do?uri=CELEX:32000L0029:en:NOT.

EPPO (European and Mediterranean Plant Protection Organization) 2009a. EPPO A1 List of pests recommend- 


\section{AGRICULTURAL AND FOOD SCIENCE}

Vänninen, I. et al. Alien invertebrate pests in Finland

ed for regulation as quarantine pests (version 2009-09). Cited 14 June 2010. Available on the Internet: http:// www.eppo.org/QUARANTINE/listA1.htm

EPPO (European and Mediterranean Plant Protection Organization) 2009b. EPPO A2 List of pests recommended for regulation as quarantine pests (version 2009-09). Cited 14 June 2010. Available on the Internet: http://www. eppo.org/QUARANTINE/listA2.htm

EPPO (European and Mediterranean Plant Protection Organization) 2010. EPPO Alert List (last updated in 201010). Cited 14 June 2010. Available on the Internet: http:// www.eppo.org/QUARANTINE/Alert_List/alert_list.htm

FAO 2002. Regulated non-quarantine pests: concept and application. International Standard for Phytosanitary Measures (ISPM) No. 16, FAO, Rome. Cited 3 Dec 2009. Available on the Internet: http://www.spc.int/PPS/ IPPC\%20ICPM\%20ISPM/ISPMs_new/Eng/ISPM_16_ English.pdf.

FAO 2004. Pest risk analysis for quarantine pests, including analysis of environmental risks and living modified organisms. International Standard for Phytosanitary Measures (ISPM) No. 11, FAO, Rome. Cited 3 Dec 2009. Available on the Internet: http://www.fao.org/docrep/008/y5874e/y5874e00.HTM

FAO 2008. Glossary of Phytosanitary Terms. International Standard for Phytosanitary Measures (ISPM) No. 5. Cited Dec 3 2009. Available on the Internet: http://www. eppo.org/QUARANTINE/ISPM05_2008_E.pdf

Germain, J.-L., Matile-Ferrero, D., Piron, M. \& Picart, J.L. 2003. Cochenilles sous serres en France : inventaire illustré. I - Les Asterolecaniidae et les Coccidae: Espaces verts, jardins et cultures ornementales. Phytoma 561: 21-23.

Germain, J. F., Matile-Ferrero, D. 2005. Les cochenilles sous serres en France: inventaire illustre. III - Les Diaspididae. Phytoma 583: 32-35

Gevrey, M., Worner, S., Kasabov, N., Pitt, J. \& Giraudel, J.L. 2006. Estimating risk of events using SOM models: A case study on invasive species establishment. Ecological Modelling 197: 361-372.

Gevrey, M. \& Worner, S. P. 2006. Prediction of global distribution of insect pest species in relation to climate by using an ecological informatics method. Journal of Economic Entomology 99(3): 979-986.

Heie, O. 1994. The Aphidoidea (Hemiptera) of Fennoscandia and Denmark. Fauna Entomolofica Scandinavica Vol. 31. Societas Entomologica Scandinavica. 242 p.

Hellmann, J. J., Byers, J.E., Bierwagen, B.G. \& Dukes, J.S. 2008. Five potential consequences of climate change for invasive species. Conservation Biology 22: 534-543.

Hickling, R., Roy, D. B., Hill, J. K., Fox, R. \& Thomas, C. D. 2006. The distributions of a wide range of taxonomic groups are expanding polewards. Global Change Biology 12:450-455.

Huber, D.M., Hughes-Jones, M., Rust, M. K., Sheffield, S. R., Simberloff, D., Taylor, C. R., Gratz, N., Menge, J. \& Thurston, H. D. 2002. Invasive pest species: impacts on agricultural production, natural resources, and the environment. Council for Agricultural Science and technology (CAST). Issue Paper number 20: 1-18. Cited 3 Dec 2009. Available on the Internet: http://www.cast-science. org/websiteUploads/publicationPDFs/ip20.pdf

IPPC 1997. International Plant Protection Convention, new revised text. FAO, Rome. $16 \mathrm{p}$.

IPCC 2007a. Climate Change 2007: The physical science basis. Contribution of Working Group I to the Fourth Assessment Report of the Intergovernmental Panel on Climate Change. Cambridge and New York: Cambridge University Press. 1009 p.

IPCC 2007b. Climate Change 2007: Climate Change impacts, adaptations, and vulnerability. Contribution of Working Group II to the Fourth Assessment Report of the Intergovernmental Panel on Climate Change. Cambridge and New York: Cambridge University Press. 976 p.

Kahanpää, J. (ed.) 2009. Draft Catalogue of Finnish Flies (Diptera: Brachycera). Cited 14 June 2010. Available on the Internet: http://www.elisanet.fi/jere.kahanpaa/diptera/list/FIdiptera.pdf

Karjalainen, S. 2008. Idänkulkusirkka Locusta migratoria (L.) Suomessa. (In Finnish). Sahlbergia 14: 22-28.

Kaukoranta, T., Tahvonen, R., Ylämäki, A. 2010. Climatic potential and risks for apple growing by 2040. Agricultural and Food Science 19: 144-159.

Kenis, M., Rabitsch, W., Auger-Rozenberg, M.-A. \& Roques, A. 2007. How can alien species inventories and interception data help us prevent insect invasions? Bulletin of Entomological Research 97: 489-502.

Kettunen J. 2008. The Checklist of Finnish Thysanoptera. The Expert Group on Finnish Hemiptera. Cited Nov 18 2010. Available at: http://www.sci.utu.fi/projects/biologia/elainmuseo/hemi/tyoryhma/Check-list_of_Finnish_ Thysanoptera.pdf

Kiritani K. 2006. Predicting impacts of global warming on population dynamics and distribution of arthropods in Japan. Population Ecology 48: 5-12.

Kullberg, J., Albrecht, A., Kaila L., Varis, V. 2008. Checklist of Finnish Lepidoptera. An updated version. Finnish Museum of Natural History, University of Helsinki. Cited 15 June 2010. Available on the Internet: http://www.fmnh. helsinki.fi/elainmuseo/hyonteiset/perhoset/index.htm

Lemmetty, A., Laamanen, J., Soukainen, M. \& Tegel, J. 2011. Emerging virus and viroid pathogen species identified for the first time in horticultural plants in Finland in 1997-2010. Agricultural and Food Science 20: 29-41.

MacLeod, A., Head, J. \& Gaunt, A. 2004. An assessment of the potential economic impact of Thrips palmi on horticulture in England and the significance of a successful eradication campaign. Crop Protection 23: 601-610.

Matile-Ferrero, D., Germain, J.-F., Picart, J.-L. \& Piron, M. 2004. Cochenilles sous serres en France: inventaire illustré. II - Les Pseudococcidae et Eriococcidae. Phytoma 572: 35-37.

McDonald, J. R., Bale, J.S. \& Walters, K.F.A. 1999. Temperature, development, and establishment potential of Thrips palmi (Thysanoptera: Thripidae) in the United Kingdom. European Journal of Entomology 96: 169-173.

McDonald, J. R., Head, J., Bale, J. S. \& Walters, K. F. A. 2001. Cold tolerance, overwintering and establishment potential of Thrips palmi. Physiological Entomology 25: 159-166.

Ministry of Agriculture and Forestry 1994. Taimiaineistolaki 16.12.1994/1205. Suomen säädöskokoelma (Finnish acts and decrees). Cited 15 June 2010. (In Finnish) Available on the Internet: http://www.finlex.fi/fi/laki/ajantasa/1994/19941205

Ministry of Agriculture and Forestry 1996. Maa- ja met- 
Vol. 20(2011): 96-114.

sätalousministeriön päätös Nro. 41/96 vihanneskasvien taimiaineiston tuottamisesta ja markkinoinnista. (In Finnish) Cited 15 June 2010. Available on the Internet: http://wwwb.mmm.fi/el/laki/kara/x/p960042.pdf

Ministry of Agriculture and Forestry 2000. Maa- ja metsätalousministeriön asetus 96/00 koristekasvien taimiaineiston tuottamisesta ja markkinoinnista. Suomen säädöskokoelma, viranomaisten määräyskokoelmat (Finnish acts and decrees, secondary legislation). (In Finnish) Cited 15 June 2010. Available on the Internet: http://www.finlex.fi/fi/viranomaiset/normi/400001/5682

Ministry of Agriculture and Forestry 2003. Laki kasvinterveyden suojelemisesta 18.7.2003/702. Suomen säädöskokoelma (Finnish acts and decrees). (In Finnish) Cited 15 June 2010. Available on the Internet: http://www.finlex.fi/fi/laki/ajantasa/2003/20030702

Ministry of Agriculture and Forestry 2006. Maa- ja metsätalousministeriön asetus nro 9/06 varmennetusta lisäys- ja taimiaineistosta. Suomen säädöskokoelma, viranomaisten määräyskokoelmat (Finnish acts and decrees, secondary legislation). (In Finnish) Cited 15 June 2010. Available on the Internet: http://www.finlex.fi/data/ normit/25058-06009fi.pdf

Ministry of Agriculture and Forestry 2008. Maa- ja metsätalousministeriön asetus (nro 17/08) kasvinterveyden suojelemisesta. Suomen säädöskokoelma, viranomaisten määräyskokoelmat (Finnish acts and decrees, secondary legislation). (In Finnish) Cited 15 June 2010. Available on the Internet: http://www.finlex.fi/data/normit/3363808017fi.pdf

Ministry of Agriculture and Forestry 2010. Maa- ja metsätalousministeriön asetus $5 / 10$ hedelmä- ja marjakasvien taimiaineiston tuottamisesta ja markkinoimisesta. (In Finnish) Cited 15 June 2010. Available on the Internet: http://www.finlex.fi/data/normit/35640-MMM_asetus_5_10.pdf

Moffitt, L. J., Stranlund, J. K., Osteen, C. D. 2008. Robust detection protocols for uncertain introductions of invasive species. Journal of Environmental Management 89, 293-299.

Norris, R. F. \& Kogan, M. 2000. Interactions between weeds, arthropod pests, and their natural enemies in managed ecosystems. Weed Science 48: 94-158.

Olesen, J. E. \& Bindi, M. 2002. Consequences of climate change for European agricultural productivity, land use and policy. European Journal of Agronomy 16: 239-262.

Paini, D. R., Worner, S. P., Cook, D. C., De Barro, D. J. \& Thomas, M. B. 2010. Using a self-organizing map to predict invasive species: sensitivity to data errors and a comparison with expert opinion. Journal of Applied Ecology 47: 290-298.

Peacock, L. \& Worner, S. 2006. Using analogous climates and global insect distribution data to identify potential sources of new invasive insect pests in New Zealand. New Zealand Journal of Zoology 33: 141-145.

Peacock, L. \& Worner, S. P. 2008. Biological and ecological traits that assist establishment of alien invasive insects. New Zealand Plant Protection 61: 1-7.
Peltonen-Sainio, P., Jauhiainen, L., Hakala, K. \& Ojanen, H. 2009. Climate change and prolongation of growing season: changes in regional potential for field crop production in Finland. Agricultural and Food Science 18: 171-190.

Rintala, T. \& Rinne, V. 2010. Suomen luteet. (Finnish bugs) (In Finnish) Hyönteistarvike TIBIALE Oy. Helsinki.

Roques, A., Rabitsch, W., Rasplus, J.-Y., Lopez-Vaamonde, C., Nentwig, W. \& Kenis, M. 2009. Alien terrestrial invertebrates of Europe. In: Handbook of alien species in Europe. Dordrecht: Springer. p. 63-79.

Schrader, G. \& Unger, J.-G. 2003. Plant quarantine as a measure against invasive alien species: the framework of the International Plant Protection Convention and the plant health regulations in the European Union. Biological Invasions 5: 357-364.

Stoate, C., Báldi, A., Beja, P., Boatman, N. D., Herzon, I., van Doorn, A., de Snoo, G. R., Rakosy, L. \& Ramwell, C. 2009. Ecological impacts of early $21^{\text {st }}$ century agricultural change in Europe - a review. Journal of Environmental Management 91: 22-46.

Stoate, C., Boatman, N.D., Borralho, R., Rio Carvalho, C., de Snoo, G. \& Eden, P. 2001. Ecological impacts of arable intensification in Europe. Journal of Environmental Management 63: 337-365.

The Finnish Expert Group on Coleoptera 2010. Atlas of the Beetles of Finland. Cited 15 June 2010. Available on the Internet: http://www.luomus.fi/elaintiede/kovakuoriaiset/index.htm

Thiele, J. \& Otte, A. 2007. Impact of Heracleum mantegazzianum on invaded vegetation and human activities. In: Pyšek, P., Cock, M. J. W., Nentwig, W. \& Ravn, H. P. Ecology and management of giant hogweed (Heracleum mantegazzianum). Wallingford UK and Cambridge, Mass., USA: CABI Publishing. p. 144-156.

Vappula, N.A. 1962. Pests of cultivated plants in Finland. Annales Agriculturae Fenniae 1, Supplementum 1 [English edition], Seria Animalia Nocentia N. 5. 239 p.

Walther, G.-R., Roques, A., Hulme, P.E., Sykes, M.T., Pysèk, P., Kühn, I., Zobel, M., Bacher, S., Botta-Dukát, Z., Bugmann, H., Czúcz, B., Dauber, J., Hickler, T., Jaros, V., Kenis, M., Klotz, S., Minchin, D., Moora, M., Nentwig, W., Ott, J., Panov, V. E., Reineking, B., Robinet, C., Semenchenko, V., Solarz, W., Thuiller, W., Vilà, M., Vohland, K. \& Settele, J. 2009. Alien species in a warmer world: risks and opportunities. Trends in Ecology and Evolution 24: 686-693.

Watts, M. J. \& Worner, S.P. 2008a. Comparing ensemble and cascaded neural networks that combine biotic and abiotic variables to predict insect species distribution. Ecological Informatics 3: 354-366.

Watts, M. J. \& Worner, S.P. 2008b. Using artificial neural networks to determine the relative contribution of abiotic factors influencing the establishment of insect pest species. Ecological Informatics 6: 4-74.

Worner, S. P. \& Gevrey, M. 2006. Modelling global insect pest species assemblages to determine risk of invasion. Journal of Applied Ecology 43: 858-867. 
Vänninen, I. et al. Alien invertebrate pests in Finland

\section{Glossary}

Pest: any species, strain or biotype of plant, animal or pathogenic agent injurous to plants or plant products (IPPC 1997; FAO 2002, 2004), even if the injurious effect is indirect through, for example, competition and harming those species that are beneficial to plants.

Alien: an organism occurring outside its natural past or present range and dispersal potential, whose presence and dispersal is due to intentional or unintentional human action (Walther et al. 2009)

Indigenous/native: an organism that has originated in a given area without human involvement or that has arrived there without intentional or unintentional intervention of humans (species/populations that arrive due to climate change do in fact arrive by natural spread, however the spread is aided by unintentional human intervention by way of anthropogenic climate warming) (Walther et al. 2009)

Introduced: direct or indirect movement by human agency, of an organism outside its past or present natural range (Walther et al. 2009)

Invasive: established alien organisms that are rapidly extending their range in the new region. Specifically: alien and invasive are not synonyms (Walther et al. 2009)

Quarantine pest: a pest of potential economic importance to the area endangered thereby and not yet present there or present but not widely distributed and being officially controlled (FAO 2004). Most quarantine pests in the sense of this definition may be classified as invasive alien species according to the interim guiding principles of the Convention on Biological Diversity (Schrader and Unger 2003).

Regulated non-quarantine pest: a non-quarantine pest whose presence in plants for planting affects the intended use of those plants with an economically unacceptable impact and which is therefore regulated within the territory of the importing contracting party. RNQPs can be present and may be widely distributed in the country to which they have arrived aided by human means (FAO 2002). See FAO (2002) for defining criteria of RNQPs and quarantine pests concerning pest status, pathway, economic impact and official control.

Non-regulated non-quarantine pest: species that are not covered by any phytosanitary regulations and against which official control measures therefore need not be applied upon interception (cf. FAO 2002); they may, of course, need management measures if they are established in the recipient country and their densities approach damage thresholds. 